\title{
Research on Teaching Reform of College English Writing Based on Big Data Analysis
}

\author{
Lili Li \\ Xianning Vocational Technical College, Xianning, 437100, China
}

Keywords: Writing teaching, College English, Big data analysis

\begin{abstract}
With the continuous development of science and technology, human society has entered the era of big data. Under the influence of big data age, the teaching of college English writing meets many opportunities. This paper analyzes the teaching advantages of English writing in the era of big data and gives some suggestions on the teaching reform of college English writing, including establishing communication platform, developing evaluation system and enhancing application abilities to provide some references for the relative researchers.
\end{abstract}

\section{Introduction}

With the development and progress of new and high technology, the era of big data has come. In higher education, the teaching of College English writing, as an important component of College English teaching, has also been affected by the large data environment. The teaching of big data writing faces more formidable challenges. Therefore, it is of great significance to strengthen the teaching model of College English writing in large data environment. One of the most obvious features of big data is its large capacity. The larger the data capacity means more data storage, more comprehensive information and more common the data reflects the problem, and large capacity is a relative concept. For example, the use of large data to build millions of questions platform accumulated a lot of students' writing samples, the amount of data is very large, but compared with the Chinese students' English learning database big data platform, it seems very small. In daily life, college students are not difficult to access to large data, and many types of data, such as audio, video, pictures of common online articles, all belong to the scope of big data. Big data has been changing work and learning life of students and these kinds of changing is invisible. In the field of learning, all kinds of learning APP realize the online course content learning, different learning resources on the network bring some impact to classroom teaching. In a word, a variety of big data not only enrich students' study and life, but also bring convenience and shortcut to English teaching. Large data processing data is very fast. This improves the speed of students' access to information and the speed of data exchange with other network platforms, and provides a very favorable objective condition for students to query English resources.

\section{Advantages of Writing Teaching of College English Based on Big Data Analysis}

Clarify Writing Objectives. Students must have some writing purpose before writing. In the traditional English writing, students are more concerned about the process of writing, neglecting the purpose of writing or what effect will the writing brings t, which led students the lack of their own thought at the time of writing and do not understand their own writing meaning and connotation. In the course of time, students will not love writing, which has seriously hindered the development of College English writing. But in the background of the era of big data, the way students using to write is no longer rigid. Students can effectively exercise and integrate the thoughts from the big data platform form their own thoughts, which is more conducive to improve the students' English writing level. We can't write just for the sake of writing. The essence of writing is the expression of thought 
and emotion. In writing teaching, the function of suppressing expression and amplifying the function of writing will inevitably distort the real purpose of writing. Writing software and online writing help systems can solve many language form problems and enable learners to concentrate more on the generation and organization of content. In the era of big data, writing teaching does not need to be separated from practice and expression. A student can be both a writer and a reader. Because the writing will receive the attention of other students, the student's writing will have the real significance, not just completes the work assigned by the teachers. In the era of big data, writing training can also be a means of creating new knowledge. For example, teachers can organize an interesting topic of discussion, students can be divided into affirmative and negative, let them combine their professional knowledge, based on collecting information, finally formed his own opinions and suggestions. Such writing is clearly not just a discipline, it will bring new knowledge and new understanding to the students involved in the discussion, and even to the administrative leaders of the university.

Enrich Writing Resources. Big data not only enriches the network course resources, but also includes corpora and their web search engines. It enables the sharing of resources among students, improves the practice and testing of English learners, and achieves the effect of quantitative change and qualitative change. Search through large data corpora, teachers can search a lot of outsources related to their teaching content of the text . Displaying audio resources in the teaching not only can broaden the students' knowledge in writing training, but also help students in various fields. The teaching of traditional English writing relies mainly on the teachers in the students' schools to explain the relevant knowledge and skills in class by means of teaching materials. In the era of big data, such dependence can largely not exist. First of all, a large number of writing teaching resources on the network provide a large and diverse guidance. These resources include both text and audio and video formats. They include both text based systems and classroom video. It has both a static introduction of teaching content, a real-time online interaction between students and students or students and teachers, both the introduction of new content and the exercises and tests of what has been learned. In addition to online teachers and curriculum resources, static and dynamic corpora, powerful search tools and web search engines can also provide effective help for English writing in college. The development of big data, relying on the multimedia and Internet platform, provides a wealth of teaching resources for the teaching of College English writing. Students with relatively poor English background can read a lot of English articles or watch English videos, and then develop English knowledge, improve their English vocabularies and improve their writing abilities.

Improve Writing Tools. In the Internet era, computers have begun to play a great role, and even replace the traditional paper writing, people naturally use it to deal with day-to-day writing work. All of these have greatly improved the efficiency of work. At the same time, it can also slow down students' pressure on College English writing. The computer has been in the process of continuous development, and in the near future, it will continue to facilitate the study of vocabulary and grammar in College English. Through the use of computers, students can quickly find ways to learn grammar, so as to improve their language skills. Most importantly, the big data age saves students' writing time. With the emergence and popularity of computers, word processing systems have largely replaced paper and pen. This greatly improves the efficiency of writing and reduces the writer's workload. With the continuous development of technology, it can be said that every stage of writing has related application software. In addition to some of the aforementioned applications in the writing preparation phase, a variety of corpus systems, online search engines, and other computer software, etc., can provide help in terms of vocabulary and so on. Some websites provide students with online, real-time feedback information about vocabulary, grammar and text. This information can help students to fill in the sentences and solve most grammatical problems in the course of writing, so as to improve the students' ability to use language and save the time when the teachers deal with the students' language mistakes. The experience English writing system developed by higher education press can provide many kinds of composition style information, help students to use related words reasonably, and improve their writing ability at the textual level. 


\section{Reform Measures of Writing Teaching of College English Based on Big Data Analysis}

Establish Communication Platform. English teaching belongs to language teaching, and the main purpose of language teaching is to train students' ability of using the language for daily communication. Therefore, language writing should be taken as the starting point in College English writing teaching. College English writing is a concrete manifestation of language use. In the context of big data, English writing has a richer connotation of language application. College English writing has three essential factors: author, text and reader. The students' grasp of these three aspects can reflect their language writing skills and their understanding of English. Therefore, teachers can apply big data to the teaching of writing so that students can accurately connect the author, the text and the reader to the relationship between the three. We can carry out the teaching of College English writing by making full use of information technology. Teachers can use cyber source to find their students more familiar and instructive film clips as writing material, rich in content and form of writing. In addition, we can also use group cooperative learning teaching mode, so that students can do writing training in cooperation, so as to improve students' interest in learning and promote students' all-round development. For example, teachers can build a web based class platform, encourage students to show their g English writing articles on the networks within the class space, which is easily accessible to other students, but also allows students to explore the skills of writing English in good communication platform. In this process, the students act as the author and the reader of the text analysis, from different angles, help students to understand the relationship between the three, and on the basis of improving students' ability to communicate in English on science to enhance students' English writing skills.

Develop Evaluation System. The traditional English writing teaching model often ignores the role played by students, leading to poor teaching of College English writing. In the era of big data, English writing teaching can be closely integrated with information technology, which provides convenient conditions for students to collect writing materials and teachers to read and write compositions. Teachers can actively construct an effective writing evaluation system, upload English writing resources in the class public network space and filter out some information which is not of great value for the students. At the same time, teachers can also use the evaluation system to understand the students' opinions about their teaching methods and discuss how to improve their English writing ability. This approach can increase students' participation in English writing teaching, and highlight the subjectivity of students. In the era of big data, the teaching of College English can not be separated from information. We need to collect the network teaching platform and students submission on the writing materials, teachers' remarks to the students' homework and the teaching presentation forms of teaching activities to support our own teaching, therefore, we should use writing teaching evaluation system combined with sufficient and appropriate teaching activities, constantly update the teaching material, teaching methods, change teaching process simplification in order to promote the level of teaching. Assessment is divided into summative assessment and formative assessment. For many years, our teaching tends to summative assessment. In order to make the evaluation system to serve teaching, teachers in the new age should combine summative assessment and formative assessment approach. Teachers should use the Internet big data continuously in the process of teaching cycle assessment of teaching effect, adjusting teaching plans and objectives. This will not only facilitate students to learn, but also more conducive to obtaining traces of students' online activities in order to facilitate the large data analysis system to provide them with more scientific, timely and personalized feedback and help. It also helps to realize the multi angle evaluation of the quality of students' writing, the teaching situation and the content of teachers' teaching and so on, so as to play a guiding role in the teaching of writing. For example, big data technology can analyze the students at present in vocabulary, syntax and discourse and the level of online activities according to the students' behavior, students' comprehensive analysis ability and shortcomings, and their improvement. In addition, teachers can use the evaluation system for technical analysis, timely understanding of students' learning status, grasp their learning difficulties. 
For example, teachers can look at students' online activities through big data, understand their current situation in vocabulary, sentence patterns and grammar, and then adjust their teaching ideas.

Enhance Applications Ability. The era of big data provides more convenient means for college English teaching. With the rapid development of information technology, teachers can effectively and effectively develop English writing teaching by constantly updating their knowledge of English and gradually improving their ability to use data and information. Students' curiosity for new things is strong. They can accept and learn new things quickly and able to fully tap the value of the new data. Therefore, teachers should fully absorb the advanced points of the era of data, and strive to adapt to the needs of social development. Schools should provide more opportunities for teachers to cultivate opportunities, so that teachers can master new skills in a timely manner and train teachers' comprehensive abilities. Besides, teachers should pay attention to the study of interdisciplinary knowledge, such as computers, corpora, communication tools. The teaching idea and the teaching pattern are two important parts in the teaching, the teaching idea has decided the teacher's teaching level from the thought, but the teaching pattern reflects the teacher's teaching quality from the behavior. In order to improve the teaching quality of English writing, English teachers should first change the traditional teaching concept, and change from the former resource provider to the resource integrator. Because of the large data and information in all directions, it is hard for students to acquire useful English learning resources. At this point, teachers should strengthen the ability to capture and analyze effective information, and selectively provide students with the individualized needs , and guide students to learn. Teachers should develop in the direction of comprehensive goals to improve teaching quality and efficiency, so as to promote the teaching of college English writing. In the era of big data, while bringing convenience to English teaching, we should also pay attention to big data and put forward higher requirements for teachers' ability to use information technology. In the era of big data, the teacher is not only the teacher of knowledge, but also the organizer and guide of teaching activities. Therefore, the relevant English teachers should constantly update their knowledge of information technology, make full use of relevant information technology, improve the quality and application level of related majors, and improve the teaching efficiency of English writing. Relevant information technology staff can also fully understand the teaching rules of English writing, so as to better develop software and teaching system suitable for students' writing learning. Through the cooperation, we can improve the teaching level of College English writing.

\section{Conclusion}

The era of big data provides a new way and platform for the teaching of college English writing, so that writing instruction can no longer be confined to textbooks, and students can be informed of their writing skills in a timely manner. Of course, the impact of the big data age on the teaching of college English writing is still in its infancy, and the teaching of English writing reform has a long way to go.

\section{References}

[1] Wang Haixiao. Reform in the Teaching of College English Writing in the Big Data Era [J]. Modern Distance Education Research, 2014(3): 66-72+86.

[2] Chen Qingbin. Reconstruction of the Teaching Model of College English Writing in the Big Data Era [J]. Foreign Language Research, 2016(3): 129-132.

[3] Yuan Changwan, Jin Shuangjun. An Empirical Study on English Writing Based on Corpus Big Data

[J]. Journal of Chongqing Jiaotong University (Social Sciences Edition), 2015, 15(4): 126-129.

[4] Li Lijun. On the Reform of College English Writing Teaching in the Big Data Era [J]. The Science Education Article Collects, 2016(6): 171-172. 